\title{
MOTIVASI BELAJAR SISWA SMK N 1 PAYAKUMBUH DALAM PEMBELAJARAN RENANG
}

\author{
Endi Ahmad \\ Correspondence: Program Studi Pendidikan Olahraga Pascasarjana UNJ, \\ Jakarta, Indonesia \\ E-mail: endiahmad077@gmail.com
}

\begin{abstract}
Abstrak
Jenis penelitian ini adalah penelitian deskriptif, populasi dalam penelitian ini adalah siswa SMK Negeri 1 Payakumbuh yang berjumlah 824 orang. Teknik pengambilan sampel secara Purposive Sampling, didasarkan pada suatu pertimbangan oleh penulis, dimana pengambilan sampel di tetapkan sebanyak $10 \%$ dari 824 yang yaitu sebanyak 82 orang. Teknik pengambilan data dengan observasi dan menyebarkan angket kepada siswa dan siswi yang telah dipilih menjadi sampel. Teknik analisis data adalah dengan menggunakan statistik deskriptif dengan tabulasi frekuensi. Hasil penelitian: Pertama, indikator 1 (hasrat keinginan berhasil) dapat dikatakan baik, karena skor rata-rata tingkat capaiannya sebesar 85,37\%. Kedua,indikator 2 (dorongan dan kebutuhan belajar) dalam pembelajaran renang dapat dikatakan cukup, tingkat capaiannya sebesar 76,49\%. Ketiga, indikator 3 (harapan dan cita-cita) dalam pembelajaran renang dapat dikatakan baik, tingkat capaiannya sebesar 89,35\%. Ke empat,indikator 4 (penghargaan dalam belajar) dikatakan baik, karena skor rata-rata tingkat capaiannya sebesar 83,78\%. Kelima, indikator 5 (kegiatan yang menarik dalam belajar) dikatakan cukup, karena skor rata-rata tingkat capaiannya sebesar 76,29\%. Keenam, indikator 6 (lingkungan belajar yang kondusif) dikatakan cukup, karena skor rata-rata tingkat capaian sebesar 77,49\%. Jadi, kesimpulan motivasi belajar siswa SMK Negeri 1 Payakumbuh dalam pembelajaran renang dengan skor rata-rata di peroleh tingkat capaian sebesar $82,28 \%$. Artinya, motivasi belajar yang dimiliki siswa dalam pembelajaran renang berada dalam kategori baik.
\end{abstract}

\section{Kata Kunci: Motivasi Belajar, Pembelajaran Renang}

\section{Pendahuluan}

Pembelajaran renang merupakan salah satu aktivitas fisik yang dapat meningkatkan kebugaran jasmani siswa, dalam hal ini aktivitas renang yang ingin penulis teliti berkaitan dengan renang pendidikan yang dilaksanakan disekolah. Pembelajaran renang yang dilakukan disekolah merupakan salah satu alat pendidikan disamping beberapa macam pelajaran lainnya, sasaran yang paling dekat disekolah adalah mengajari anak untuk bisa berenang dari tidak dapat berenang, kegiatan ini mempunyai arti tersendiri dalam pendidikan, yaitu mengubah rasa takut terhadap air menjadi tidak takut terhadap air, maka akan timbul rasa percaya terhadap diri sendiri sehingga proses belajar ini menjadi salah satu keunikan dalam belajara renang bagi siswa.

Proses pembelajaran renang yang dilalaksanakan disekolah dipengaruhi beberapa hal yang berkaitan dengan kemampuan, semangat ataupun motivasi untuk belajar yang dimiliki siswa itu sendiri. Sardiman (2010) dengan 
"Memberikan motivasi kepada seseorang siswa, berarti menggerakkan siswa untuk melakukan sesuatu atau ingin melakukan sesuatu".

Olahraga renang merupakan olahraga dengan aktifitas di air yang membawahi cabang-cabang olahraga lainnya, seperti loncat indah, polo air, renang indah dan olahraga renang perairan terbuka, renang merupakan olahraga yang dilaksanakan di air dan yang paling di kenal dan digemari banyak orang dari mulai anak-anak sampai dengan orang tua. Menurut keperluannya olahraga renang dapat dijadikan olahraga prestasi, renang pendidikan di sekolah-sekolah dan untuk kesehatan bagi pelakunya, pembelajaran renang adalah suatu proses pembelajaran di air melalui aktivitas jasmani yang bertujuan untuk merangsang pertumbuhan dan perkembangan peserta didik serta untuk meningkatkan kemampuan dan keterampilan, kecerdasan dan pembentukan watak serta nilai dan sikap yang positif bagi peserta didik dalam rangka untuk mewujudkan tujuan pendidikan.

Memperkenalkan kegiatan renang kepadasiswa akan meningkatkan perkembangan harmonis mereka, memperbaiki pengembangan multilateral kardio-pernafasan,perkembangan mental dan fisik multilateral anak, melalui proses koordinasi motorik yang signifikan,pengembangan otot, keterampilan kognitif dan sarana interaksi sosial.Hamalik (2012) Istilah motivasi menunjuk kepada "semua gejala yang terkandung dalam stimulasi tindakan kearah tujuan tertentu di mana sebelumnya tidak ada gerakan menuju ke arah tujuan tersebut. Motivasi dapat berupa dorongan-dorongan dasar atau internal dan intensif diluar diri individu atau hadiah. Sebagai suatu masalah dalam kelas, motivasi adalah proses membangkitkan, mempertahankan, dan mengontrol minat-minat. Oemar (2012) mengatakan "Motivasi adalah suatu perubahan energi di dalam pribadi seseorang yang ditandai dengan timbulnya afekti dan reaksi untuk mencapai tujuan". Sejalan dengan pendapat tersebut, selanjutnya Uno (2014) istilah motivasi berasal dari kata motif yang dapat diartikan "sebagai kekuatan yang terdapat dalam diri individu tersebut bertindak atau berbuat". Motif tidak dapat diamati secara langsung tetapi dapat diinterpretasikan dalam tingkah lakunya, berupa rangsangan, dorongan, atau pembangkit tenaga munculnya tingkah laku tertentu.

Sardiman (2010) motivasi belajar adalah "merupakan faktor psikis yang bersifat non-intelektual, peranannya yang khas adalah dalam hal penumbuhan gairah, merasa senanag dan semangat untuk belajar". Uno (2014) indikator motivasi belajar dapat diklasifikasikan sebagai berikut: a. Adanya hasrat dan keinginan berhasil. b. adanya dorongan kebutuhan belajar, c.Adanya harapan akan cita-cita, d. Adanya penghargaan dalam belajar, e. Adanya kegiatan yang menarik dalam belajar, f. Adanya lingkungan belajar yang kondusif dan kegiatan belajar yang menarik. Sardiman (2010). Motivasi intrinsik merupakan "motif-motif yang berfungsi tidak perlu dirangsang dari luar, karena dalam diri setiap individu sudah ada dorongan untuk melakukan sesuatu". Selanjutnya Uno (2014) menyatakan "motivasi yang terkait pemaknaan dan peranan kognisi lebih merupakan motivasi intrinsik, yaitu motivasi oyang muncul dari dalam, seperti minat atau keinginan (curiosity),motivasi intrinsik sangat diperlukan untuk keterampila anak-anak

PJKR 
sehingga kemampuan mereka berkembang dengan baik. Orang tua dengan segala bentuk tuntutan dan tekanan dapat mempenaruhi motivasi intriksik anak, oleh sebab itu orang tua mesti paham dengan anak dan mampu mengenali anak dengan baik untuk meningkatkan motivasi dalam diri anak tersebut. Sardiman (2010) motivasi ektrinsik adalah "motif-motif yang aktif berfungsinya karena ada perangsang dari luar", motivasi intrinsik dapat juga dikatakan sebagai bentuk motivasi yang datang dari luar, adanya aktivitas belajar dimulai dan diteruskan berdasarkan dorongan dari luar yang tidak secara mutlak berkaitan dengan kemampuan yang dimiliki individu dalam belajar.

\section{Metode}

Berdasarkan masalah dan tujuan penelitian, maka penelitian ini tergolong pada penelitian deskriptif. Variabel bebas dalam penelitian ini adalah Motivasi belajar siswa dan untuk Variabel terikatnya adalah pembelajaran Renang. Populasi adalah keseluruhan subjek penelitian, Suharsimi (2010) populasi dalam penelitian ini adalah seluruh siswa dan siswi SMKN 1 Payakumbuh yaitu kelas X, XI, yang berjumlah 824 orang, dikecualikan untuk siswa-siswi kelas XII yang telah mengikuti ujian Nasinal Untuk kelulusan akhir sekolah.

Arikunto (2010) sampel adalah sebagian atau wakil populasi yang diteliti, kemudian dalam penelitian initeknik pengambilan sampel yang digunakan adalah Purposive Sampling, yaitu didasarkan pada suatu pertimbangan oleh penulis, dimana sampeldiambil sebesar $10 \%$ dari 824 siswa/i sehingga diperoleh sampel sebanyak 82 orang.

Insturmen untuk mengumpulkan data dalam penelitian ini adalah berupa kuesioner atau angket, Setiap pertanyaan mempunyai lima alternatif jawaban yang dipilih dengan berdasarkan pada skala likert. Sesuai dengan jenis dan sumber data, maka teknik yang digunakan dalam pengumpulan data pada penelitian ini yaitu: dengan menggunakan teknik penyebaran angket (kuesioner). Kuesioner atau angket dibagikan langsung kepada peserta didik yang akan dijadikan sampel.

Data yang dikumpulkan dalam penelitian ini kemudian di analisis dengan menggunakan analisis teknis deskriptif dari Sudjana (1989).

$$
\begin{aligned}
& P=\frac{F}{N} x 100 \% \quad \text { Keterangan: } \mathrm{P}=\text { Persentase, } \mathrm{F}=\text { Frekuensi, } \\
& \text { N=Jumlah sampel } \\
& 90-100 \%=\text { Sangat baik } \\
& 80-89 \%=\text { Baik } \\
& 65-79 \%=\text { Cukup } \\
& 55-64 \%=\text { Kurang } \\
& 0-54 \% \quad=\text { Kurang Sekali }
\end{aligned}
$$

\section{Pembahasan}

Untuk mendapatkan data tentang Motivasi belajar siswa dalam PembelajaranRenang Di SMKN Negeri 1 Payakumbuh kota payakumbuh berdasarkan faktor motivasi belajar yang terdiri dari sub indikator 1 (Hasrat keinginan barhasil), indikator 2 (dorongan dan kebutuhan belajar), indikator 3 
(harapan dan cita-cita, keinginan yang menarik dalam belajar), indikator 4 (lingkungan belajar yang kondusif). Dimana untuk motivasi belajar siswa dalam pembelajaran renang ini terdapat 31 pernyataan dengan 5 kategori jawaban yang dipilih responden atau sampel yaitu sangat setuju (SS), setuju (S), ragu-ragu (KS), tidak setuju (TS) dan sangat tidak setuju (STS) serta dengan 82 orang sampel. Untuk lebih jelasnya dapat dilihat pada Tabel berikut ini:

Tabel 1. Deskripsi Data Distribusi Frekuensi Motivasi Belajar Siswa dalam Pembelajaran Renang

\begin{tabular}{|c|c|c|c|c|c|c|}
\hline No. & Variabel & Indikator & $\begin{array}{l}\text { Jumlah } \\
\text { skor yang } \\
\text { diperoleh }\end{array}$ & $\begin{array}{l}\text { Jumlah } \\
\text { skor ideal }\end{array}$ & Persentase & Keterangan \\
\hline 1 & \multirow{6}{*}{$\begin{array}{l}\text { Motivasi } \\
\text { belajar } \\
\text { dalam } \\
\text { pembelajan } \\
\text { renang }\end{array}$} & $\begin{array}{l}\text { Hasrat keinginan } \\
\text { berhasil }\end{array}$ & 2800 & 3280 & $85,37 \%$ & Baik \\
\hline 2 & & $\begin{array}{l}\text { Dorongan dan } \\
\text { kebutuhan dalam } \\
\text { belajar }\end{array}$ & 1670 & 2050 & $81,46 \%$ & Baik \\
\hline 3 & & $\begin{array}{l}\text { Harapan dan cita- } \\
\text { cita }\end{array}$ & 1099 & 1230 & $89,35 \%$ & Baik \\
\hline 4 & & $\begin{array}{l}\text { Penghargaan } \\
\text { dalam belajar }\end{array}$ & 2061 & 2460 & $83,78 \%$ & Baik \\
\hline 5 & & $\begin{array}{l}\text { Kegiatan yang } \\
\text { menarik dalam } \\
\text { belajar }\end{array}$ & 1564 & 2050 & $76,29 \%$ & Cukup \\
\hline 6 & & $\begin{array}{l}\text { Lingkungan } \\
\text { belajar yang } \\
\text { kondusif }\end{array}$ & 1270 & 1640 & $77,44 \%$ & Cukup \\
\hline Tot & skor & & 10464 & 12710 & $82,28 \%$ & Baik \\
\hline
\end{tabular}

Berdasarkan table diatas faktor motivasi belajar siswa indikator 1 didapat 2800 jumlah skor dari 3280 skor ideal dengan rerata tingkat capai diperoleh sebesar $85,37 \%$, motivasi belajar siswa indikator 2 (dorongan dan kebutuhan belajar) didapat jumlah skor 1670 dari jumlah skor ideal 2050 dengan rerata diperoleh tingkat capai sebesar $81,46 \%$, motivasi belajar siswa indikator 3 (harapan dan cita-cita) didapat 1099 jumlah skor dari 1230 jumlah skor ideal dengan rerata diperoleh tingkat capai sebesar $89.35 \%$, motivasi belajar siswa indikator 4 (penghargaan dalam belajar) di peroleh 2061 jumlah skor dari 2460 jumlah skor ideal capai sebesar $83.78 \%$, motivasi belajar siswa indikator 5 (kegiatan yang menarik dalam belajar) didapat 1564 jumlah skor dari 2050 jumlah skor idealdengan rerata diperoleh tingkat capai sebesar $76,29 \%$, belajar siswa indikator 6 (kegiatan yang menarik dalam belajar) didapat 1234 jumlah skor dari 1640 jumlah skor ideal dengan rerata di peroleh tingkat capai sebesar 77,44\%,

Untuk melihat lebih rinci tentang motivasi siswa SMKN 1 Payakumbuh dalam pembelajaran renang secara keseluruhan melalui distribusi frekuensi dan persentase dapat dilihat pada diagram berikut: 


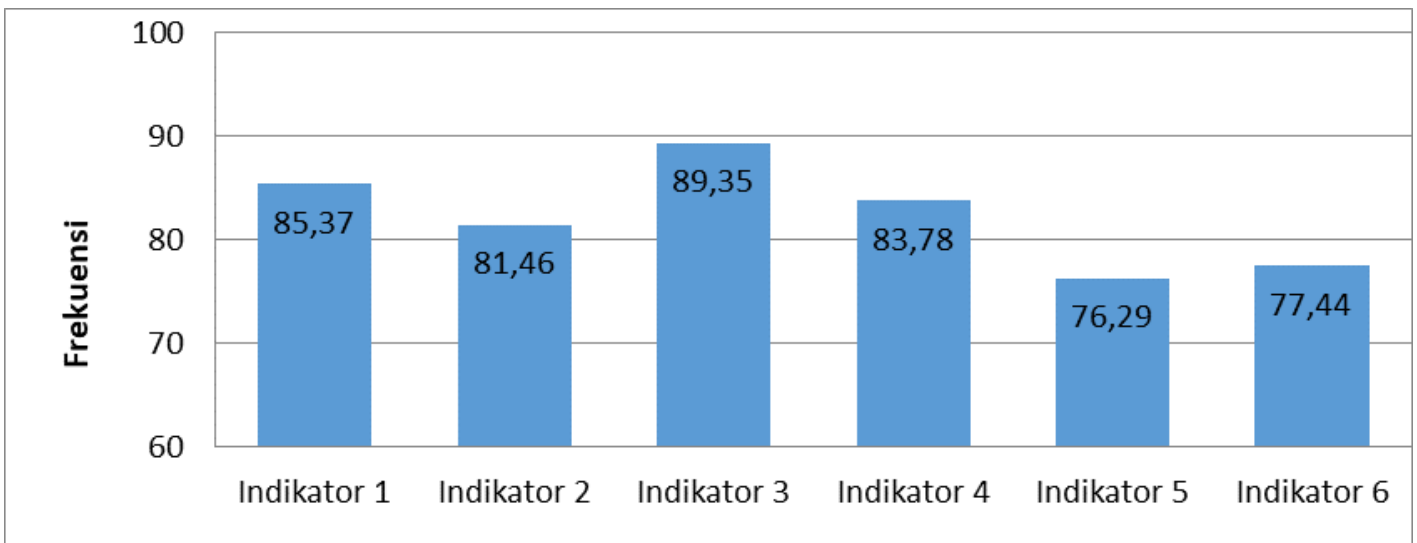

Gambar 1. Tingkat Motivasi belajar Siswa SMK N 1 Payakumbuh dalam Sembelajaran Renang Secara Keseluruhan

Dengan termotivasinya siswa dalam proses belajar bila dilaksanakan secara berkelanjutan senantiasa menumbuhkan kemauan dan kerja keras pada diri siswa, sehingga apabila disalurkan secara baik dapat dihubungkan dengan tujuannya untuk berprestasi. Memperhatikan pengaruh yang diakibatkan dengan adanya motivasi belajar siswa menimbulkan kesan kiranya faktor ini dapat terus dikembangkan dalam usaha menumbuhkan dan mengembangkan motif siswa sesuai dengan potensi yang dimilikinya, dilihat dari indikator motivasi belajar siswa dalam pembelajaran renang dan jawaban responden untuk kriteria kriteria indikator 1 (Hasrat keiinginan berhasil) diperoleh tingkat capaian sebesar 85.37\%, ini tergolong kategori baik. Dengan demikian hasrat dan kemauan siswa dalam belajar renang biasa dikatakan baik ini terlihat dari semangat yang dimiiki siswa saat proses pembelajaran renang berlangsung.

Indikator 2 (Dorongan dan kebutuhan dalam belajar) diperoleh capaian sebesar $76.49 \%$, tingkat capaian ini tergolong kedalam kategori baik, dengan demikian dapat kita katakan bahwa indikator dorongan dan kebutuahan belajar siswa dalam pembelajaran renang biasa dikatakan baik ini terlihat pada saat pembelajaran yang di terapkan di sambut dengan baik oleh siswa dan siswi serta siswa dan siswi mau melaksanakan tanpa harus di suruh oleh guru penjasa dalam pada saat pelajaran renang berlangsung.

Indikator 3 (Harapan dan cita-cita) diperoleh tingkat capaian sebesar $89.35 \%$, tingkat capaian ini tergolong ke dalam kategori baik, berdasarkan tingkat capaian tersebut untuk indikator harapan dan cita-cita dalam pembelajaran renang, berarti siswa memiliki keinginan dan kemauan yang kuat untuk dapat belajar renang dengan baik ini terlihat pada saat proses belajar renang di yang diikuti siswa tersebut.

Indikator 4 (Penghargaan dalam belajar) diperoleh tingkat capaian sebesar $83.78 \%$, tingkat capaian ini tergolong ke dalam kategori baik, berdasarkan tingkat capaian tersebut indikator penghargaan dalam belajar renang siswa akan lebih akan lebih rajin dalam pembelajaran renang tersebut jika di berikan penghargaan atau diberikan hadiah dan lain-lain. 
Indikator 5 (Kegiatan yang menarik dalam belajar) di peroleh tingkat capaian sebesar $76.29 \%$, tingkat capaian ini tergolong ke dalam kategori cukup, berdasarkan tingkat capaian ini indikator kegiatan yang menarik dalam belajar renang, siswa tidak begitu senang dengan peroses belajar renang tersebut ini terlihat saat guru memberikan materi renang, mungkin disebabkan guru kurang mampu menjelaskan materi sehingga siswa kurang tertarik belajar renang

Indikator 6 (Lingkungan belajar yang kondusif) diperoleh tingkat capaian sebesar 77,44\%, tingkat capaian ini tergolong ke dalam kategori cukup, berdasarkan tingkat capaian tersebut indikator 6 lingkungan belajar yang kondusif dalam belajar renang, siswa kurang semangat dalam peroses pembelajaran renang ini disebabkan lingkungan tempat berenang yang kurang memadai untuk peroses belajar renang yang baik.

Dari beberapa indikator motivasi belajar siswa dalam pembelajaran renang di SMKN 1 Payakumbuh diatas, Berdasarkan temuan penelitian dilihat dari hasil analisis penelitian secara keseluruhan, dilihat secara rata-ratapada variabelmotivasi belajar renang maka diperoleh tingkat capaian sebesar 82,28\%, maka dapat disimpulkan bahwa motivasi Belajar siswa SMKN 1 Payakumbuh dalam pembelajaran renang dengan hasil 82,28\% dapat dikategorikan baik.

Jadi, untuk mencapai kategori sangat baik diperlukan lagi tingkat capai sebesar $17.72 \%$, ini perlu diperhatikan seorang guru pendidikan jasmani atau guru pembimbing renanguntuk lebih meningkatkan motivasi siswa dan siswinya baik secara internal maupun eksternal untuk menimbulkan semangat belajar renang yang sangat baik agar tercapai tujuan dari pembelajaran renang itu sendiri dengan baik. Motivasibelajar yang tinggi haruslah ditumbuhkan pada siswa dalam rangka mencapai prestasi yang lebih tinggi. Apabila seorang siswa sudah memiliki motivasi belajar yang lebih tinggi maka siswa akan berusaha ikut secara aktif dan partisipatif dalam setiap pembelajaran yang diberikan.

\section{Simpulan}

Setelah diadakan penelitian tentang Motivasi belajar siswa SMK Negeri 1 Payakumbuh dalam pembelajaran Renang, maka dapat diambil kesimpulan Motivasi belajar siswa SMK Negeri 1 Paykumbuh dalam pembelajaran renang dengan skor rata-rata variabel motivasi belajar renang yang diteliti peroleh tingkat capaian $82,28 \%$ artinya motivasi belajar yang dimiliki siswa terhadap pembelajaran Renang di SMKN 1 Payakumbuh berada dalam keadaan baik. Indikator-indikator yang diteliti mempunyai hubungan yang erat dengan keberhasilan siswa dalam menjaga motivasi untuk belajar renang, namun guru masih belum menyadari materi pembelajaran renangperlu disediakan fasilitas atau sarana prasarana, sehingga motivasi siswa mengikuti pembelajaranrenang tetap terjaga dengan baik, hal ini tentu perlu diteliti kembali untuk mengetahui motivasi guru terkait dalam memberikan materi renang kepada siswa dan siswi. 


\section{Rujukan}

Andri Aritianto, 2015. Pengaruh Pengembangan Pembelajaran Renang Gaya Dada Terhadap Keterampilan Renang Gaya Dada. Jurnal Pendidikan Olahraga dan Kesehatan Volume 03 Nomor 02, 355 - 360

Arikunto \& Suharsimi, 2010. Prosedur Penelitian: Suatu Pendekatan Praktek. Jakarta: PT Rineka Cipta

Christi Woolger and Thomas G. Power, 2011. Parenting and Children's Intrinsic Motivation in Age Group Swimming. Journal of Applied Developmental Psychology, 596

Daniela, 2015. The playful behavior in swimming and its interferences in 1-3 years child's development. Journal of Social and Behavioral Sciences, 1230-1231

Eka Nugraha, 2010. Aktivitas Pembelajaran Renang Bagi Siswa SD (Penelitian Tindakan Terhadap Siswi SDN Nagrog Cicalengka. Jurnal Pendidikan Jasmani dan Olahraga Volume 2 Nomor 1. 103-104

Hamalik, Oemar, 2012. Psikologi Belajar dan Mengajar. Bandung: Sinar Baru Algasindo

Hamzah Uno, 2014. Teori Motivasi dan Pengukurannya. Jakarta: Bumi Aksara Cet. $\mathrm{Ke} 11$

I W. Setaya.I W Santiasa, 2013. Penerapan Model Pembelajaran Langsung Berbantuan Pemodelan Untuk Meningkatkan Motivasi Dan Prestasi Belajar Renang. Journal Program Pascasarjana Universitas Pendidikan Ganesha Program Studi Teknologi Pembelajaran. Volume 3

Muhammad Ali, 2012. Pengembangan Pendekatan Kontekstual Terhadap Hasil Belajar Renang Gaya Dada. Jurnal penelitian Universitas Jambi. Volume 14, Nomor 2, Hal. 57-68

Ridwan \& Sunarto, 2012. Pengantar Statistika. Bandung: Alfabeta

Suryabrata \& Sumai, 2012. Psikologi Pendidikan. Jakarta: Rajawali Pers

Sardiman. 2010. Interaksi dan Motivasi Belajar Mengajar. Jakarta: Rajawali Pers.

PJKR_

http://jurnal.unimed.ac.id/2012/index.php/jpehr/index 